\title{
Factors Affecting the Way Financial Consumers in Turkey Regard Internet Banking
}

\author{
İsmail YILDIRIM \\ Hitit University \\ Department of Finance, Banking and Insurance \\ Çorum, Turkey \\ ismailyildirim@hitit.edu.tr
}

\begin{abstract}
Although the number of Internet users is ever increasing, the number of Internet banking users has not increase as expected. In order to get to the core of this problem, it is critical to understand how personal preferences and perceptions of customers affect the internet banking use. This study investigates the factors affecting the way financial consumers regard Internet banking, using the Technology Acceptance Model (TAM). In this respect, four hypotheses were developed as part of the framework of this research. Surveys were developed in order to collect data; the data was then delivered to academics working in Turkish universities. Three hundred and forty two surveys were then analyzed. Data obtained was analyzed using the structural equality model. According to the findings of the analysis, the most important factor affecting the intention to use Internet banking for financial consumers is the perception of trust. Easeof-use, convenience and security considerations were among the other factors affecting the intention to use internet banking.
\end{abstract}

Keywords: Turkish Banking Industry, Technology Acceptance Model, Internet Banking, Structural Equality Model

\section{INTRODUCTION}

As a result of the advancements in communication and information technologies, especially the financial product specifications, and due to the intensified competition in the industry, the banking industry is going through a radical change globally (Sohail and Shanmugham, 2003). This change is also affecting the way financial consumers conduct their banking transactions (Eriksson et al., 2008), (Sayar and Wolfe, 2007).

Today, the most traditional banks are using internet technologies and offering online banking services to their customers. As a result, consumers are now able to conduct any bank transaction such as fund transfers between accounts, accessing their 
accounts, viewing their account statements, pay their bills, etc. from anywhere at any time visiting the website of their bank.

The use of Internet banking offers several advantages both to banks and their customers. Internet banking services are accessible 24/7. It makes it possible for banks to reach their customers easily and allows their customers to save on costs (Xue, Hitt and Chen, 2011). The use of Internet banking reduces branch, personnel and rent expenses while making it possible for banks to offer innovative and diverse products, to improve their marketing operations and communication, and to provide services regardless of geographic location and time (Mols, 1999), (Devlin, 1995).

According to the data obtained from The Banks Association of Turkey, the total number of Internet banking customers in Turkey is 34,048,000 as of December, 2014. The number of individual customers who logged in at least once in the past year is approximately 19,615,000 (The Banks Association of Turkey, 2014). The Internet bank users in Turkey are using Internet banking tools for financial transactions (fund transfer, payments, etc.) and investment (investment funds, forex, etc.) to a high degree.

The use of Internet banking must be widespread in order to be able to take advantage of the Internet banking as expected. Financial consumers must be motivated to use internet banking if the use of Internet banking is to be widespread. Therefore, the main purpose of this study is to identify the factors affecting the way financial consumers use Internet banking. This study consists of two chapters. The first chapter covers the literature scan made on this subject and gives information about the technology acceptance model. The second chapter addresses the results of the survey which provides an insight on the factors affecting the use of Internet banking.

\section{LITERATURE REVIEW}

Several researches are available in literature on the use of Internet banking. Among these are Vrechopoulous and Atherinos, (2009), Polasik and Wisniewski (2008), Ekberg, Li and Morina (2007), Nor and Pearson (2007), Sanmugam (2007), Flavian, et al. (2006), Shergill and Li (2006), Rotchanakitumnuai and Speece (2003), Sohail and Shanmugham (2003), Suh and Han (2002), Karjaluoto et al. (2002), Matilla, Karjaluoto and Pento (2003), Sathye (1999).

Vrechopoulous and Atherinos, (2009) reported that the design of online banking website has an effect on the Internet usage behavior. Polasik and Wisniewski (2008) suggested that factors such as a perceived security level, having an experience with Internet at an average level, and demographic variables play a significant role in the adoption of Internet banking. Ekberg, Li and Morina (2007) in their study involving 4 leading banks operating in Sweden, investigated the principles banks take into consideration when deciding on using Internet banking. They reported that security concerns have an impact on the use of Internet banking. Nor and Pearson (2007) in their study conducted in Malaysia, reported that factors such as trust, relative superiority, trialability have an impact on the use of Internet banking. Sanmugam (2007) suggested that the most important factor in the adoption of Internet banking is the social norms.

Flavian, et al. (2006) reported that factors such as trust in the bank, income level of the customer, customer's age and gender played a significant role in the customer's preference to use the Internet banking services provided by his/her bank. Shergill and Li (2006) conducted research with the aim, to identify the factors affecting the trust and 
loyalty New Zealanders place in Internet banking. In their study they found that shared values was the most important factor influencing the trust bank customers place in Internet banking? On the other hand, they have found that factors such as customer satisfaction from Internet banking, trust, brand image and expenses played an important role in the customer's loyalty to the bank. Rotchanakitumnuai and Speece (2003) investigated the obstacles to the adoption of Internet banking for corporate bank customers in Thailand. The study revealed that concerns about Internet security is the most important obstacle for the widespread use of Internet banking. Sohail and Shanmugham (2003) in their study conducted in Malaysia, reported that factors such as accessibility, knowledge about Internet banking, resistance to change, capital costs of computers and access to the Internet, trust in the bank, security concerns, advantages and ease-of-use influence the adoption of Internet banking. Matilla, Karjaluoto and Pento (2003) conducted a study on the Internet banking customers aged 65+ who are living in Finland. Aspects such as inconvenience, security and being deprived of personalized services are among the obstacles of using Internet banking.

Suh and Han (2002) investigated the viewpoint of consumers in Korea using a survey embedded to the websites of 5 banks. They reported that advantages and ease-ofuse have an impact on the use of Internet banking by financial consumers. They also stated that the element of trust was one of the most important measures influencing the use of Internet banking. Karjaluoto et al. (2002) conducted a study on the Internet banking customers living in Finland. They reported that security concerns did not have a significant impact on the use of Internet banking. Sathye (1999) in the study conducted in Australia reported that factors such as security concerns and not being sufficiently informed about Internet banking were among the obstacles of adopting Internet banking.

Among the studies which use the technology acceptance model are Daneshgadeh and Y1ldirım (2014), Yoon and Steege (2013), Alsajjan and Dennis (2010), Gu, et al. (2009), Cheng, et al. (2006), Luarn and Lin (2005), Pikkarainen, et al. (2004), Eriksson, et al. (2004).

Daneshgadeh and Y1ldirım (2014) investigated the factors affecting the way Turkish bank customers use Internet banking. They have noted that ease-of-use and advantages were the most important factors in the use of Internet banking. Yoon and Steege (2013) in their study, listed openness, availability of the website, and security concerns of the customers as the factors affecting the use of Internet banking. Alsajjan and Dennis (2010) used the technology acceptance model in their study. They collected the data through a survey distributed to 618 university students in Saudi Arabia. It was found that trust and advantages were among the factors affecting the use of Internet banking.

$\mathrm{Gu}$, et al. (2009) investigated the attitude of Korean consumers towards mobile banking adding several external variables along with trust variate to the technology acceptance model. The study showed that perceived ease-of-use and perceived convenience had an impact on the intention while perceived convenience had a correlation with perceived ease-of-use. Cheng, et al. (2006) investigated the factors influencing the intention of bank customers in Hong Kong to use Internet banking including a perceived web security variable to the technology acceptance model. This 
study showed that variables such as perceived convenience and perceived web security had an effect on the intention to use while perceived ease-of-use had an indirect impact.

Luarn and Lin (2005) investigated the factors affecting the intention to use Internet banking in Taiwan including variables such as credibility, perceived selfefficacy, perceived financial cost along with perceived convenience and perceived easeof-use. This study showed that perceived credibility had a more significant effect when compared to the traditional variables of the technology acceptance model.

Pikkarainen, et al (2004) added four new variables to the technology acceptance model (perceived playfulness, knowledge about Internet banking, security and privacy, quality of the Internet connection) and investigated the factors affecting the adoption of Internet banking in Finland. According to this study, knowledge about Internet banking has an effect on the adoption of online banking; while the effect of factors such as perceived playfulness, security and privacy, quality of the Internet connection were statistically insignificant. In another study, Eriksson, et al. (2004) investigated the viewpoint of bank customers in Estonia towards Internet banking using the technology acceptance model. This study emphasized that users of Internet banking services agree on the advantages of Internet banking. Therefore, the study states the key role perceived convenience plays in the use of Internet banking.

This study was conducted with the addition of variables such as perceived trust and security to the technology acceptance model developed by Davis (1986). In this respect, it is expected to contribute to the literature.

\section{CONCEPTUAL FRAMEWORK AND RESEARCH HYPOTHESES}

This study aims to identify the factors affecting the way financial consumers use Internet banking. The model used in this study is based on the Technology Acceptance Model developed by Davis (1986). Technology Acceptance Model is commonly used in the estimation of factors affecting the technology use patterns of individuals.

The Technology Acceptance Model is recognized by most of the researchers conducting studies in the field of information technologies (Luarn and Lin, 2005). Several studies available in the literature showed that the Technology Acceptance Model is a solid and consistent model in explaining technology acceptance behaviors of individuals for a wide range of technologies (Gefen et al., 2003). The model reveals the significance of perceived advantage and ease-of-use for the usage patterns of system users. It supports that ease-of-use and perceived advantage along with external factors of the technology usage model affects the usage preferences of individuals (Park et al. 2009). Technology usage model is shown in Figure 1.

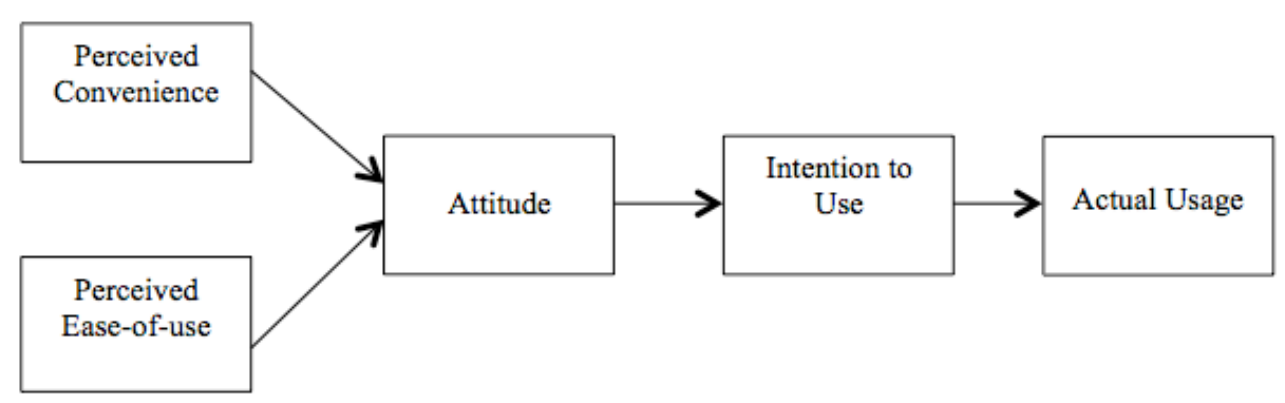

Figure 1: Technology Acceptance Model, Source: Davis et al. 1989 
According to the technology acceptance model, two important viewpoints, namely perceived convenience and perceived ease-of-use, play an important role in shaping the intention of individuals to accept and use information technologies. Perceived convenience is defined as the belief that the use of a specific system will improve one's work performance. Perceived ease-of-use, on the other hand, can be defined as the degree one believes a system does not require too much effort (Davis, 1989).

The research model developed for this study aims to investigate the main factors affecting the use of Internet banking as mentioned above. The research model is based on aspects such as trust, convenience, security, and ease-of-use. The research model expands the horizon of the previous studies with the addition of aspects such as security and trust. Research model developed is shown in Figure 2.

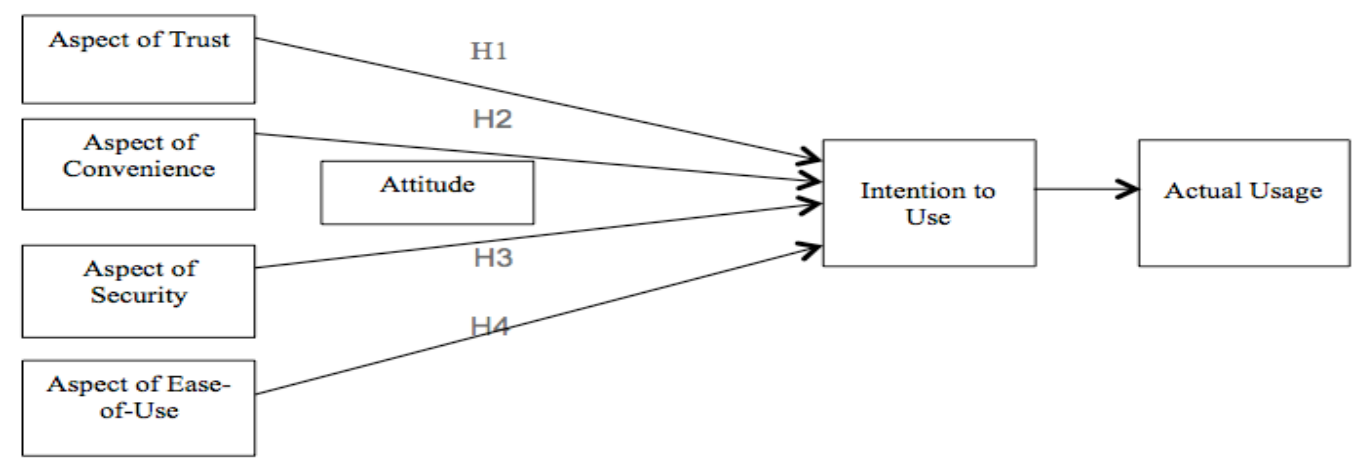

Figure 2: Research Model

Research hypotheses developed based on the research model are as follows:

Hypothesis 1: A customer's perception of trust has a positive effect on the intention to use Internet banking.

Hypothesis 2: A customer's perception of convenience has a positive effect on the intention to use Internet banking.

Hypothesis 3: A customer's perception of security has a negative effect on the intention to use Internet banking.

Hypothesis 4: A customer's perception of ease-of-use has a positive effect on the intention to use Internet banking.

\section{Research Method}

\subsection{Measurement}

At this phase, "Confirmatory Factor Analysis" was used in order to define the variables available in the scale. "Confirmatory Factor Analysis" is used in order to reduce and summarize the data, in other words, rendering many hidden variables into controllable factors (Yap and Khong, 2006).

The scales used to validate the research must represent the selected products in general (Kerlinger and Lee, 2000). Therefore, previous research was taken as a basis in order to validate the elements selected for the research model. A 2-section survey was 
developed in order to make it possible. The first section of the survey includes questions directed at definitive data. It provides demographic information with nine questions aimed at gender, age, educational status, experience in the use of Internet and Internet banking. The second section of the survey includes additional factors of trust and security along with perceived ease-of-use and perceived convenience already available in the Technology Acceptance Model.

Perceived ease-of-use as a scale of this study was developed using the study of Gefen et al. (2003), while perceived convenience was developed using the studies conducted by Cheng et al. (2006), Kim et al. (2008) and Lopez et al. (2008).Perceived security was developed using the studies conducted by Kim et al. (2008), (2010) and Chang and Chen (2009). Questions related with perceived security were developed using the studies conducted by Gu et al. (2009) and Suh and Han (2002).All the scales available in this study involved options in 5-point Likert style. Then, the reliability of the variables of the scale was tested (Cronbach's alfa) and confirmatory factor analysis was performed in order to estimate the validity of the scale.

\subsection{Data Collection}

A number of academicians working in universities located in Turkey participated in this study. Participants were submitted with surveys using online technologies. Surveys were delivered to 1,328 academicians through e-mail. Three hundred and forty two responses were received. All 342 surveys were then analyzed. All of the participants were Internet users as the research was conducted online. Surveys were then analyzed using SPSS and AMOS software.

Table 1 shows the demographic distribution of the participants. $74 \%$ of the participants were male while $26 \%$ were women. Almost half of the participants (48\%) are in the age group between 19 and 30. Ones with 6 to 10 years of computer experience account for $54 \%, 55 \%$ of the participants use Internet daily, $60 \%$ of the participants use Internet banking for their financial transactions (money transfer, utility payments, bank wire, etc.).

Table 1: Demographic Specifications of the Participants

\begin{tabular}{|l|l|c|c|}
\hline Demographic Specification & Category & Frequency & Percentage (\%) \\
\hline \multirow{4}{*}{ Age } & between 19 and 30 & 165 & 48 \\
\cline { 2 - 4 } & between 31 and 40 & 102 & 30 \\
\cline { 2 - 4 } & between 41 and 50 & 55 & 16 \\
\cline { 2 - 4 } & $50+$ & 20 & 6 \\
\hline \multirow{4}{*}{ Gender } & Female & 90 & 26 \\
\cline { 2 - 4 } & Male & 252 & 74 \\
\hline \multirow{5}{*}{ Frequency of Internet usage } & Less than a year & 6 & 2 \\
\cline { 2 - 4 } & 1 to 5 years & 61 & 18 \\
\cline { 2 - 4 } & 6 to 10 years & 185 & 54 \\
\cline { 2 - 4 } & $10+$ years & 90 & 26 \\
\hline \multirow{5}{*}{ Internet banking transactions } & Daily & 187 & 55 \\
\cline { 2 - 4 } & Weekly & 140 & 41 \\
\cline { 2 - 4 } & Monthly & 95 & 28 \\
\hline & Account statement checks & 206 & 60 \\
\cline { 2 - 4 } & Financial transactions & 31 & 9 \\
\cline { 2 - 4 } & Investment transactions & 10 & 3 \\
\cline { 2 - 4 } & Other & & \\
\hline
\end{tabular}




\section{Data Analysis and Results}

\subsection{Scale Validation}

It is possible to calculate the internal consistency of structural equality model along with reliability and validity calculations peculiar to structural equality model. Several analyses were conducted for the selected scale. Table 2 shows values related to the scale used in this study.

Table 2. Values of the Scale Model

\begin{tabular}{|l|c|c|c|c|}
\hline \multicolumn{1}{|c|}{ Factor } & Cronbach's $\alpha$ & $\begin{array}{c}\text { Reliability of } \\
\text { the Structure }\end{array}$ & Average & $\begin{array}{c}\text { Explained } \\
\text { Variation }\end{array}$ \\
\hline Trust & .921 & .929 & 3.35 & .66 \\
\hline Convenience & .887 & .916 & 3.43 & .68 \\
\hline Security & .908 & .933 & 4.05 & .74 \\
\hline Ease-of-use & .730 & .861 & 3.38 & .64 \\
\hline
\end{tabular}

Cronbach's alpha values were estimated for each factor. These values are in the range of 0.73 and 0.92 . These values were above .70 for each scale which defines the reliability of a scale (Nunnally and Bernstein 1994). Reliability and explained variation are among the other values investigated in the reliability and validity calculations of structural equality model. Explained variation is recognized as a proof of the convergence validity. It is recommended that both these values should be 0.5 or above (Hair et al. 2006). Table 3 shows the results of the explanatory factor analysis.

Table 3: Results of the Explanatory Factor Analysis

\begin{tabular}{|l|c|c|c|c|}
\hline \multicolumn{1}{|c|}{ Factor } & F1 & F2 & F3 & F4 \\
\hline A. Reliability & .714 & & & \\
A1 & .743 & & & \\
A2 & .781 & & & \\
A3 & .709 & & & \\
A4 & & .847 & & \\
\hline B. Convenience & & .810 & & \\
B1 & & .837 & & \\
B2 & & & & \\
B3 & & & .854 & \\
B4 & & & .851 & \\
\hline C. Security & & & .893 & \\
C1 & & & .812 & \\
C2 & & & & \\
C3 & & & & .695 \\
C4 & & & & .712 \\
\hline D. Ease-of-use & & & & .681 \\
D1 & 46.315 & 54.21 & 62.41 & $\mathbf{7 2 . 1 4}$ \\
D2 & & & & \\
D3 & & & \\
D4 & & & \\
\hline Cumulative explanatory variance & & & \\
\hline
\end{tabular}


This is followed by factor reduction using principal components analysis and varimax rotation technique. Factors with 0.5 or above factor loading are selected (Lee, 2009). Four factors and 16 variables were identified which account for $72 \%$ of the total variance.

\subsection{Model Test}

Figure 3 shows the results of the model test. The model represents $72 \%$ of the variance of the use of Internet banking.

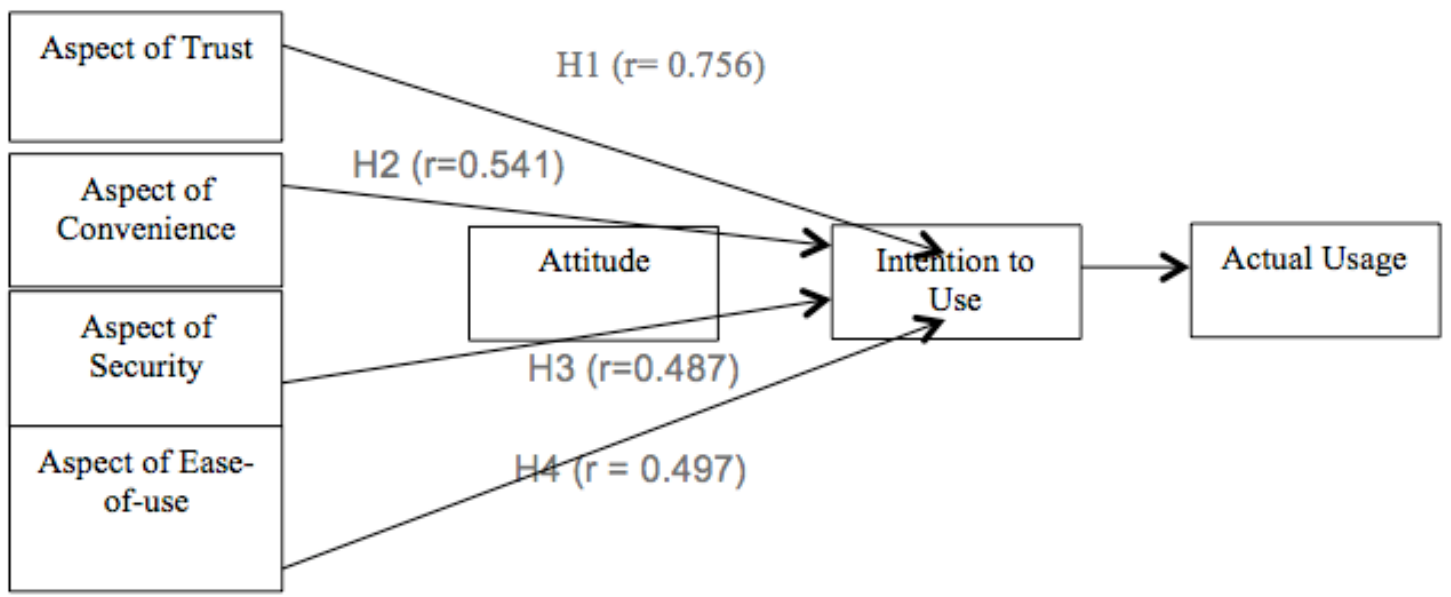

Figure 3: Results of the Model Test

Hypothesis 1, tests the correlation between a customer's perception of trust and his/her intention to use Internet banking. According to the model, perceived trust ( $\mathrm{r}=$ .756) has a positive and significant effect on the intention to use $(t=10.147)$. Thus, Hypothesis 1 is accepted.

Hypothesis 2, tests the correlation between a customer's perception of convenience and his/her intention to use Internet banking. According to the model, perceived convenience $(\mathrm{r}=.541)$ has a positive and significant effect on the intention to use $(\mathrm{t}=9.142)$. Thus, Hypothesis 2 is accepted.

Hypothesis 3, tests the correlation between a customer's perception of security and his/her intention to use Internet banking. According to the model, perceived security $(r=.487)$ has a positive and significant effect on the intention to use $(\mathrm{t}=8.698)$. Thus, Hypothesis 3 is accepted.

Hypothesis 4, tests the correlation between a customer's perception of ease-of-use and his/her intention to use Internet banking. According to the model, perceived easeof-use $(\mathrm{r}=.497)$ has a positive and significant effect on the intention to use $(\mathrm{t}=7.598)$. Thus, Hypothesis 4 is accepted.

Test results of the model confirm the positive and significant correlations between perceived trust, perceived convenience, perceived security and perceived ease-of-use and the intention to use Internet banking separately. 
It is possible to say that a model is reliable if the parameters of the model are in the required range. The sample size has a significant impact on the estimation of the coherence of the model. Sufficient sample size is determined by the total sample size of the number of variables involved. According to the literature, sample size must involve at least 100 individual entries or it should be 10 times more than the number of variables in the normal distribution (Jaafar and Rafiq, 2005).

A model developed with taking some of the parameters of a defined model as zero or giving them a fixed value is considered as a sub-model of the original and this intertwined models strategy plays an important role in structural equality model. The validity of one model over the other is decided by the chi-square difference and the assessment of statistical significance of the difference between degrees of freedom of the models. Correlations which do not contribute to the goodness of fit index of the model are ruled out according to the parsimony principle (Raykov and Marcoulides, 2006). Fit indices of the model developed in this study are shown in Table 4.

Table 4: Fit Indices of the Model

\begin{tabular}{|l|l|l|}
\hline Fit Indices of the Model & $\begin{array}{l}\text { Measured } \\
\text { Value }\end{array}$ & Accepted Value \\
\hline$\chi 2 /$ df & 1.895 & $\leq 3.00$ \\
\hline Root Mean Square Residual (RMR) & .048 & $0-1$ \\
\hline Comparative Fit Index (CFI) & .954 & $\geq 0.90$ \\
\hline Root Mean Square Error of Approximation (RMSEA) & .0654 & $.05-.08$ \\
\hline Relative Fit Index (RFI) & .957 & $\geq 0.90$ \\
\hline Goodness of Fit Index (GFI) & .951 & $\geq 0.90$ \\
\hline
\end{tabular}

( $\left.\chi^{2 / \mathrm{df}}\right)$ and Root Mean Square Residual, Comparative Fit Index, Root Mean Square Error of Approximation, Relative Fit Index, Goodness of Fit Index were used to estimate the fitness of the model developed in this study. All fit indices are in the acceptable range. These findings prove the plausibility of the model.

\section{CONCLUSION}

This study investigated the correlations between four factors and the intention to use Internet banking using the model developed. The survey prepared for this purpose was submitted to academicians working in several universities in Turkey using online resources. Three hundred and forty two responses were then included in the analysis as they were found eligible. The findings of this research are limited with the scope of this study.

Factors affecting the way financial consumers adopt Internet banking were investigated based on the Technology Acceptance Model. Perceived ease-of-use as a scale of this study was developed using the study of Gefen et al. (2003), while perceived convenience was developed using the studies conducted by Cheng et al. (2006), Kim et al. (2008) and Lopez et al. (2008). Perceived security was developed using the studies conducted by Kim et al. (2008), (2010) and Chang and Chen (2009). Questions related with perceived security were developed using the studies conducted by $\mathrm{Gu}$ et al. (2009) and Suh and Han (2002). All the scales available in this study involved options in 5-point Likert style. Then, the reliability of the variables of the scale was tested (cronbach's alpha) and confirmatory factor analysis was performed in order to estimate the validity of the scale. 
Hypothesis developed as part of the research model used were then subjected to statistical analyses. According to the findings of the analysis, the most important factor affecting the intention to use internet banking for financial consumers was found to be the perceived trust $(\mathrm{r}=.756)$. This finding complies with the literature (Gu et al. 2009, Cheng et al. 2006, Luarn and Lin, 2005). The result suggests that individuals may start using Internet banking if they trust in this technology. Banks need to develop an online Internet banking service which will give the trust financial consumers require.

According to the other hypothesis results, perceived convenience $(r=.541)$ has a positive and significant effect on the intention to use. Perceived ease-of-use $(\mathrm{r}=.497)$ has a positive and significant effect on the intention to use. This finding complies with the literature (Gu et al. 2009, Cheng et al. 2006, Luarn and Lin, 2005, Eriksson et al. 2004).

Perceived security $(r=.487)$ has a positive and significant effect on the intention to use. This study shows that the perceived security of financial consumers affects the intention to use Internet banking both directly and through attitude. In other words, their intention to use Internet banking is reduced as their security perception increases. These findings comply with the findings of Lee (2009).

It is important for the banks to take these findings in consideration in order to popularize the use of Internet banking. Being able to have financial consumers use Internet banking will reduce the time and space banks have to invest in order to provide services to their customers. 


\section{Appendix: Survey}

Chapter 1
A. Age
(19 to $30 / 31$ to $40 / 41$ to $50 / 50+$ )
B. Gender
(Female / Male)
C. You have been a computer user for how many years?
(Less than a year / 1 to 5 years / 6 to 10 years / 10+ years)
D. Frequency of Internet usage
(Daily / Weekly / Monthly)
E. Which transaction is most common for you in terms of Internet banking?
Account statement checks
Financial transactions
Investment transactions
Other

Chapter 2

A. Perceived Trust

A.1 Internet banking is trustable.

A.2 Internet banking serves for the interests of the customer.

A.3 Transactions in Internet banking are reliable.

A.4 Internet banking meets its responsibilities.

B. Perceived convenience

B.1 Internet banking transactions are completed quickly.

B.2 Internet banking is advantageous.

B.3 I am able to complete my financial transactions easily using Internet banking.

B.4 Internet banking removes the challenges of geographical limitations.

C. Perceived security concern

C.1 I am concern about security when making transactions using Internet banking.

C.2 I am concern about the security of my personal information when making transactions using Internet banking.

C.3 I am concerned about the security of my Internet banking username and password.

C.4 It might be possible for other to access my account if I used Internet banking.

D. Perceived Ease-of-use

D.1 It is easy to use Internet banking for banking transactions.

D.2 Internet banking is easy-to-use.

D.3 It is easy to learn how to make transactions using Internet banking.

D. 4 I can make transactions with Internet banking without any mistake. 


\section{REFERENCES}

Alsajjan, B., Dennis C. (2010). Internet Banking Acceptance Model: Cross-Market Examination, Journal of Business Research 63 (2010) 957-963.

Chang, H., Chen, S. (2009). Consumer Perception Of Interface Quality, Security, And Loyalty In Electronic Commerce. Information \& Management, 46(7), 411-417.

Cheng, T.C.E., Lam D.Y.C., Yeung, A.C.L.. (2006). Adoption of Internet Banking: An Empirical Study in Hong Kong, Decision Support Systems, 42:1558-1572.

Daneshgadeha, S., Yıldırım, S.Ö. (2014). Empirical Investigation Of Internet Banking Usage: The Case Of Turkey, Procedia Technology 16, 322 - 331.

Davis, F. D. (1986). A Technology Acceptance Model for Empirically Testing New End-User Information Systems: Theory and Results. Ph.D. Thesis, Sloan School of Management, Massachusetts Institute of Technology.

Davis, F.D., Bagozzi, R.P., Warshaw, P.R. (1989). User Acceptance of Computer Technology: A Comparison of Two Theoretical Models, Management Science, 35 (8): 982-1003.

Devlin, J. F. (1995). Technology and Innovation in Retail Banking Distribution, International Journal of Bank Marketing, 13(4), 19-25.

Ekberg, P. L., Gentiana S.M (2007). On-line Banking Access System Principles behind Choices and Further Development, Seen From a Managerial Perspective, Jönköping University.

Eriksson, K., Kerem, K., Nilsson, D. (2008). The adoption of commercial innovations in the former central and eastern European markets: The case of internet banking in Estonia. International Journal of Bank Marketing, 26(3), 154-169.

Eriksson, K., Kerem, K., Nilson, D.. (2004). Customer Acceptance of Internet Banking in Estonia, International Journal of Bank Marketing, 23 (2): 200-216.

Flavian, C., Guinaliu, M., Torres, E. (2006). How Bricks and Mortar Attributes Affect Online Banking Adoption, International Journal of Bank Marketing, 24 (6): 406423.

Gefen, D., Karahanna, E. and Straub, D. W. (2003). Trust and TAM in Online Shopping: An Integrated Model. MIS Quarterly. 27(1): 51-90.

Gu, J., Lee, S., Suh, Y. (2009). Determinants of Behavioral Intention to Mobile Banking, Expert Systems with Applications, 36: 11605-11616.

Hair, J. F., Black, W., Anderson, R., Babin, B. R. and Tahtam, R. L. (2006). Multivariate Data Analysis with Readings. London: Mcmillan Book Company.

Jaafar, H.S., Rafiq, M. (2005). Customers' Perceptions of Service Quality by TPL Service Providers in the United Kingdom - A Confirmatory Factor Analysis, Research Methodologies in Supply Chain Management: 187-202.

Karjaluoto, H., Matilla, M. Ve Pento, T. (2002). Electronic banking in Finland: consumer beliefs and reactions to a new delivery channel. Journal of Financial Services Marketing. 6 (4), pp. 346-361. 
Kerlinger, F., Lee, H. (2000). Foundations Of Behavioral Research (4th ed.). Cambridge, England: Cambridge University Press.

Kim, D. J., Ferrin, D. L., Rao, H. R. (2008). A Trust-Based Consumer Decision-Making Model in Electronic Commerce. The role of trust, perceived risk, and their antecedents. Decision Support Systems, 44(2), 544-564.

Luarn, P. ve Lin, H. (2005). Toward an Understanding of the Behavioral Intention to Use Mobile Banking, Computers in Human Behavior, 21: 873-891.

Matilla, M., Karjaluoto , H., Pento, T. (2003). Internet Banking Adoption among Mature Customer: Early Majority Or Laggards? Journal of Service Marketing, Vol.17, No. 5, pp. 514-528.

MOLS, Niels, P., BUKH, P.,Nikolaj ve NIELSEN, Jorn, F. (1999), "Distribution Channel Strategies in Danish Retail Banking" International Journal of Retail \& Disribution Management, 27(1), 37-47.

Nor, K.Md. ve Pearson, J.M.. (2007). The Influence of Trust on Internet Banking Acceptance, Journal of Internet Banking and Commerce, 12 (2): 1-10

Nunnally, J. C., \& Bernstein, I. H. (1994). Psychometric theory. McGraw, New York: McGraw-Hill.

Park, N., Roman, R., Lee, S. and Chung, J, E. (2009). User Acceptance of Digital Library Systems in Developing Countries: An Application of the Technology Acceptance Model. International Journal of Management, 29: 196-209.

Pikkarainen, T., Pikkarainen, K., KarJjaluoto, H., Pahnila, S.. (2004). Consumer Acceptance of Online Banking: An Extension of the Technology Acceptance Model, Internet Research, 14 (3): 224-235.

Polasik, M. ve Wisniewski, T.P.. (2008). Empirical Analysis of Internet Banking Adoption in Poland, International Journal of Bank Marketing, 27 (1): 32-52.

Raykov, T., \& Marcoulides, G. A. (2006). On Multilevel Model Reliability Estimation From the Perspective of Structural Equation Modeling. Structural Equation Modeling, 13, 130-141.

Rotchanakitumnuai, S. ve Speece, M.. (2003). Barriers to Internet Banking Adoption: A Qualitative Study Among Corporate Customers in Thailand, International Journal of Bank Marketing, 21 (6), 312-323.

Sanmugam, A.. (2007). Factors Determining Consumer Adoption of Internet Banking, http://papers.ssrn.com/sol3/papers.cfm?abstract id=1021484\#,

Sathye, M.. (1999). Adoption of Internet Banking by Australian Consumers: An Empirical Investigation, International Journal of Bank Marketing, 17 (7): 324334.

Sayar, C., \& Wolfe, S. (2007). Internet banking market performance. Turkey versus the UK. International Journal of Bank Marketing, 25(3), 122-141.

Shergill, G.S. ve Li, B.. (2006). Internet Banking-An Empirical Investigation of a Trust and Loyalty Model for New Zealand Banks, Journal of Internet Commerce, 4 (4): $101-118$. 
Sohail, M.S. and Shanmugham, B. (2003). E-Banking and Customer Preferences in Malaysia: An Empirical Investigation. Information Science, 150, pp. 207-217.

SUH, B. and HAN, I. (2002) Effect of trust on customer acceptance of Internet banking. Electronic Commerce Research and Applications, 1, 247-263.ss.

Vrechopoulous, Adam and Atherinos, Evagelos (2009), Web Banking Layout Effects on Consumer Behavioural Intentions, International Journal of Bank Marketing, 27(7), 524-546

Xue, M., Hitt, L. M., \& Chen, P. (2011). Determinants and outcomes of internet banking adoption. Management Science, 57(2), 291-307.

Yap, B.W., Khong, K.W. (2006). Examining The Effects of Customer Service Management (CSM) on Perceived Business Performance via Structural Equation Modelling, Applied Stochastic Models in Business and Industry, 22: 587-605.

Yoon, H.S., Steege, L.M.B. (2013). Development of a quantitative model of the impact of customers' personality and perceptions on Internet banking use, Computers in Human Behavior 29 (2013) 1133-1141. 